\title{
Bacteriophages and their applications
}

\author{
${ }^{1 *}$ Thung, T.Y., ${ }^{1,2}$ Lee, E., ${ }^{3}$ Premarathne, J.M.K.J.K., ${ }^{4}$ Nurzafirah, M., ${ }^{5}$ Kuan, C.H., \\ ${ }^{6}$ Elexson, N., ${ }^{1}$ Tan, C.W., ${ }^{1}$ Malcolm, T.T.H., ${ }^{1}$ New, C.Y., ${ }^{1}$ Ramzi, O.S.B., ${ }^{1}$ Nuzul, N.J., \\ ${ }^{7}$ Noor Azira, A.M., ${ }^{7}$ Ungku Fatimah, U.Z.A. and ${ }^{1,2}$ Son, R. \\ ${ }^{1}$ Department of Food Science, Faculty of Food Safety and Technology, Universiti Putra Malaysia, 43400 \\ Serdang, Selangor, Malaysia \\ ${ }^{2}$ Food Safety and Food Integrity, Institute of Tropical Agriculture and Food Security, Universiti Putra \\ Malaysia, 43400 Serdang, Selangor, Malaysia \\ ${ }^{3}$ Department of Livestock and Avian Science, Faculty of Livestock, Fisheries and Nutrition, Wayamba \\ University of Sri Lanka, Makandara, 60170 Gonawila, Sri Lanka \\ ${ }^{4}$ Department of Diagnostic and Allied Science, Faculty of Health and Life Science, Management and \\ Science University, 40100 Shah Alam, Selangor, Malaysia \\ ${ }^{5}$ Department of Agricultural and Food Science, Faculty of Science, Universiti Tunku Abdul Rahman, 31900 \\ Kampar, Perak, Malaysia \\ ${ }^{6}$ Department of Biology Molecule, Faculty of Resource Science and Technology, Universiti Malaysia \\ Sarawak, 94300 Kota Samarahan, Sarawak, Malaysia \\ ${ }^{7}$ Department of Food Service and Management, Faculty of Food Safety and Technology, Universiti Putra \\ Malaysia, 43400 Serdang, Selangor, Malaysia
}

\begin{abstract}
Article history:
Received: 13 March 2018

Received in revised form: 7

April 2018

Accepted: 11 April 2018

Available Online: 16 April 2018
\end{abstract}

Keywords:

Bacteriophages,

Properties,

Application

DOI:

https://doi.org/10.26656/fr.2017.2(5).082

\begin{abstract}
Bacteriophages are ubiquitous in our world, mainly in the oceans, soil, the water and food we consume. They can be used efficiently in modern biotechnology, as well as alternatives to antibiotics for many antibiotic resistant bacterial strains. Phages can be used as vehicles for vaccines both DNA and protein, for the detection of pathogenic bacterial strain, as biocontrol agents in agriculture and food industry. This review outlines the properties as well as the influence of different external physical and chemical factors like temperature and acidity on phage persistence. A better understanding of the complex problem of phage sensitivity to external factors may be useful for other researchers working with phages. Furthermore, the applications of bacteriophages were described in this paper as well.
\end{abstract}

\section{Introduction}

Bacteriophages or phages are natural enemies of bacteria and hence man friends to fight bacterial infections. In fact, bacteriophages were first discovered dates back to the second decade of the $20^{\text {th }}$ century (Twort, 1915; Goodridge and Abedon, 2003) and their bactericidal activity was first reported by Ernest Hankin in 1896 (Sulakvelidze et al., 2001). Accordingly, phages are ten times more numerous in the environment than bacteria, with an estimated number of $10^{32}$ bacteriophages (Brüssow and Kutter, 2005). Based on their self-replicating and self-limiting, bacteriophages offer a great advantage over antibiotics as the amplification continues at the site of infection as long as the hosts are present. Currently, over 5500 different bacteriophages, having genetic information encoded by double-stranded DNA, single-stranded DNA, doublestranded RNA and single-stranded RNA, have been discovered (Ackermann, 2007). The most abundant group of lytic bacteriophages belong to tailed dsDNA viruses (Myoviridae, Podoviridae and Siphoviridae), order of Caudovirales (Wittebole et al., 2014). Important commercial bacteriophage preparations available are Agriphage $^{\mathrm{TM}}$, EcoShield ${ }^{\mathrm{TM}}$, ListShield ${ }^{\mathrm{TM}}$, Listex $^{\mathrm{TM}} \mathrm{P} 100$ and Salmonellex ${ }^{\mathrm{TM}}$ (Madhusudana Rao and Lalitha, 2015). The outstanding attributes of bacteriophages for treating zoonotic pathogens are their short generation time, non-toxicity, high specificity to the bacterial host, and they do not affect the viability of other flora in the environment (Hudson et al., 2013; Rong et al., 2014; Jamal et al., 2015). Thus, intensive research efforts have been focused on the prevalence of bacteriophages from different sources in order to accelerate or to expand their 
applications in various fields. For instance, bacteriophages have been isolated from different types of food products, including chicken meat, ground beef, roast turkey breast, ruminant-based foods, cheese, oil, raw skim milk, common carp and marine fish, sardine, clam, mussels, shellfish, shrimp, and vegetables (Sulakvelidze and Barrow, 2005). In light of the increasing interest in bacteriophages, studies were undertaken not only to enumerate and to evaluate their lysis efficacy, but also to enhance our immediate understanding of this virulence bacteriophage. For these purposes, bacteriophages need to be purified and characterized. Upon methodological approaches, bacteriophages can be purified by polyethylene glycol (PEG) precipitation (Han et al., 2014) or cesium chloride (CsCl) gradients centrifugation (Wong et al., 2014), and characterized in terms of morphology, genomic DNA, proteomic and biological measurements of phage-host infections (Yang et al., 2010; Sun et al., 2012; Tiwari et al., 2013). Work on characterization and recent applications were reviewed in this paper.

\section{Classification}

In 1973, the International Committee on Taxonomy of Viruses (ICTV) was formed to authorize and organize the taxonomic classification of and the nomenclatures of viruses. Importantly, classification is mainly used for the following purposes in order to identify novel bacteriophages, to detect the relationships among bacteriophages, to maintain bacteriophage databases and collections. Besides, it can be used for identification of either bacteriophages with therapeutic and industrial applications, or harmful bacteriophages in biotechnology and fermentation industry for control and eradication purpose (Kutter and Sulakvelidze, 2005).

Bacteriophages are classified into 13 families based on the nature of their encapsidated nucleic acid and their virion morphology (Hanlon, 2007). There are 9 families with dsDNA: Corticoviridae (icosahedra capsid with lipid layer), Fuselloviridae (pleomorphic, envelope, lipids, no capsid), Lipothrixviridae (enveloped filaments, lipids), Myoviridae (contractile tail), Plasmaviridae (pleomorphic, envelope, lipids, no capsid), Podoviridae (short, non-contractile tail), Rudiviridae (helical rods), Siphoviridae (long, non-contractile tail) and Tectiviridae (icosahedral capsid with inner lipoprotein vesicle) (Figure 1). Inoviridae (rod-shaped with helical symmetry) and Microviridae (icosahedral capsid) exhibited in ssDNA. Two families with dsRNA and ssRNA are Cystoviridae (enveloped, icosahedral capsid, lipids) and Leviviridae (quasi-icosahedral capsid), respectively. Ackermann (2007) reported that more than $96 \%$ of all bacteriophages are tailed phages, which

belong to the order of the Caudovirales. Besides, their properties are extremely varied, such as their dimensions and fine structure, DNA content and composition, nature of constitute proteins, serology, host range, and physiology (Kutter and Sulakvelidze, 2005). The three main families comprising the Caudovirales with $60 \%$ of the characterized phages are Siphoviridae, 25\% are Myoviridae and 15\% are Podoviridae (Ackermann and Dubow, 1987; Kutter and Sulakvelidze, 2005; Lopes et al., 2014). However, only $3-4 \%$ of the studied phages (polyhedral, filamentous, and pleomorphic) belong to 10 families, where some of which are very small (Ackermann, 2007).

ssDNA

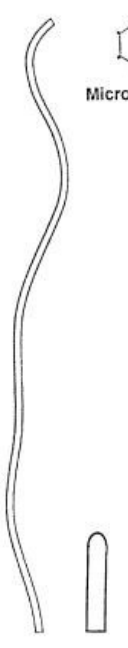

Inoviridae

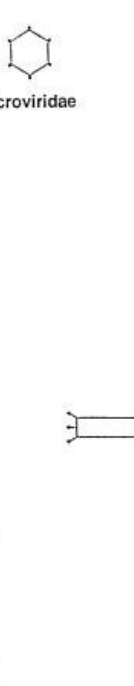

Figure 1. Bacteriophages morphotypes

(Source: Ackermann and Dubow, 1987)

\section{Life cycles}

Since bacteriophages lack an own metabolism, they completely rely on the energy and protein biosynthetic machinery of their bacterial hosts to reproduce. Therefore, bacteriophages infect bacteria and can propagate in two possible ways; lytic life cycle and lysogenic life cycle. It is known that virulent phages go through lytic cycle, where firstly attach to the target host by binding to specific cell wall receptors such as peptidoglycan, lipopolysaccharide, oligosaccharide and teichoic acid (Lenski, 1988; Weinbauer, 2004; Elbreki et al., 2014). This binding specificity might occur at the cell capsule, flagella and/or conjugative pili (Hanlon, 2007). Thereafter, phages will inject its genome into the host bacteria, leaving the viral capsid outside of the cell. Then, the viral DNA is transcribed by host's RNA polymerase, leading to redirect the bacteria's metabolic machinery to produce more phages. Finally, new phages will assemble in abundance, and phage progeny are released upon bacterial cell lysis. According to Kutter 
and Sulakvelidze (2005), bacteriophage lytic enzymes (endolysins or lysins) play an important role in breaking down the bacterial cell wall structure (peptidoglycan) during the final stage of the lytic cycle. In addition, some phages with filamentous morphology are capable to escape from the host cell via cell wall extrusion without causing destruction of the host (Hanlon, 2007). In lysogenic cycle, temperate phages insert its nucleic acid (the prophage) in the host genes, where it remains silent for extended periods without any metabolic consequences for the host cell (Elbreki et al., 2014). This prophage genome is vertically transmitted along with the whole bacterial chromosome to its progeny until the lytic cycle is induced (Weinbauer, 2004). Previously, Ranquet et al. (2005) have shown that a temperate phage ' $\mathrm{Mu}$ ' can switch between lysogeny and lytic growth under the influence of high temperature and stationary phase.

Apart from the two life cycles, Ackermann and Dubow (1987) proposed that a unique condition referred as pseudolysogeny (unstable carrier-state), where phage genomes act like a prophage regardless either virulent or temperate phage might occur. Under stressful conditions, phage genomes coexist in an unstable relationship with bacterial cells for extended periods, which mainly resulted from a low energy state affected by several factors like at low temperatures in the bacterium, concentration of nutrients accessible or the presence of antibiotics in the bacterial cell (Ripp and Miller, 1997). Thus, the metabolism of the bacterium is slow and generation times increased. Nonetheless, if unfavorable conditions are removed or the nutrients are provided to the bacterium, the pseudolysogens resolve and enter into either lysogenic cycle or lytic cycle (Ripp and Miller, 1998).

\section{Enumeration, concentration and purification of bacteriophages}

The main requirement for developing "bacteriophage technology" for practical purpose is the ability to quantitate viable bacteriophages accurately and reproducibly. Plaque assays is a simple enumeration procedure, where several dilutions of the phage preparation are gently mixed with a permissive host bacterium in molten agar and dispersed evenly on the surface of the agar medium. After incubation, a clear circular area of lysed cells known as plaque will develop in a confluent lawn of host bacterium on the agar medium (Anderson et al., 2011). Lately, the double agar overlay or soft agar overlay methods of plaque assay are most commonly used approach for determining phage titers. This technique has been used by researchers with Bacillus (Shin et al., 2011), Campylobacter (Premarathne et al., 2017), Escherichia (Cormier and
Janes, 2014), Klebsiella (Kęsik-Szeloch et al., 2013), Salmonella (Thung et al., 2017), Staphylococcus (Li and Zhang, 2014), Vibrio (Peng et al., 2014) and others. Furthermore, phage particles can also be enumerated by other methods such as electron microscopy or fluorescent microscopy (Table 1).

Table 1. Methods for enumeration of bacteriophages

\begin{tabular}{|c|c|}
\hline Technique & Method features \\
\hline Plaque assay & - Good detection limit \\
\hline $\begin{array}{l}\text { Transmission electron } \\
\text { microscopy (TEM) }\end{array}$ & $\begin{array}{ll}\text { - } & \text { Total counts } \\
\text { - } & \text { Morphological } \\
\text { characterization }\end{array}$ \\
\hline $\begin{array}{l}\text { Epifluorescence } \\
\text { microscopy }\end{array}$ & $\begin{array}{ll}\text { - } & \text { Total counts } \\
\text { - } & \text { No detection limit for } \\
\text { environmental samples } & \\
\text { - } & \text { Relatively rapid } \\
\text { - } & \text { High precision }\end{array}$ \\
\hline
\end{tabular}

(Source: Weinbauer, 2004)

The concentration of infectious particles is prerequisites for structural and functional characterization of bacteriophages. Methods used to concentrate phages are filter-adsorption-elution, flocculation and ultracentrifugation. Additionally, filtration through $0.2-0.4 \mu \mathrm{m}$ pore-size filters followed by ultrafiltration was applied to avoid losses of infectivity. For example, Jun et al. (2013) had employed $0.45 \mu \mathrm{m}$ membrane filter followed by centrifugation to increase the titer of bacteriophage pSF-1, which infects Shigella flexneri. Bourdin et al. (2014) reported that phage lysates of T4-like Escherichia coli phages were concentrated by different centrifugation and through 0.22 $\mu \mathrm{m}$ membrane filter without titer loss. In some cases, PEG precipitation is applied in the concentration of phage particles procedure. It was used to prepare high titers of Salmonella-specific phages by Bao et al. (2011), Wong et al. (2014), Bao et al. (2015) and other researchers.

Considering the distinct variability characteristic of bacteriophages such as size, density, nucleic acid content and resistance mechanical stressors (Thurber et al., 2009), the choice of purification methods are known to influence the degree of specific phages purity. Centrifugation in $\mathrm{CsCl}$ gradients is ideal for purifying large amounts of phage, where the contaminant like bacterial lipopolysaccharide (i.e. endotoxin) can be removed from the phage preparations, resulting highly purified yields (Carlson, 2005). Kleiner et al. (2015) had used $\mathrm{CsCl}$ density gradient centrifugation for virus-like particles (VLP) purification and illustrated the significance of phage density among the samples. Previously, $\mathrm{CsCl}$ density gradient ultracentrifugation was widely used in bacteriophage purification such as Acinetobacter baumannii phage ФAB2 (Lin et al., 2010), 
Bacillus cereus phage JBP901 (Shin et al., 2011), Salmonella enterica serovar Typhimurium phage $\Phi$ st 1 (Wong et al., 2014) and Staphylococcus aureus phage SPW (Li and Zhang, 2014).

\section{Properties of bacteriophages}

Bacteriophages are differentiated on the bases of their morphology. Thus, electron microscopy is often the easiest and fastest way for phage identification, as well as to assign an unknown phage to a family (Ackermann, 2007). Akhtar et al. (2014) had employed TEM to characterize a collection of Salmonella enterica lytic bacteriophages isolated from animal feces and sewage samples. The phages in the collection were mostly Siphoviridae and Myoviridae. Meanwhile, Pope et al. (2007) had used cryo-electron microscopy to characterize a purified cyanophage Syn5 which hostspecific to Synechococcus WH8109 strain. They reported that the capsid has a single 'horn', a novel fibrous structure protruding from the opposing end of the capsid from the tail of the virion.

On the other hand, phage structural proteins are most commonly analyzed by sodium dodecyl sulfatepolyacrylamide gel electrophoresis (SDS-PAGE). This is partly because one can describe the bands not just in terms of their relative mobility to each other, but also in terms of their molecular size. For the identification of Salmonella Enteritidis phage PVP-SE1 structural proteins, twenty-one protein bands with molecular masses ranging from $14,000 \mathrm{Da}$ to $94,000 \mathrm{Da}$ were estimated by SDS-PAGE (Santos et al., 2011). A CsClpurified bacteriophage vB_SenS-Ent1, host-specific to Salmonella Enteritidis was isolated from swine effluent, which consisted of nine polypeptide chains with molecular weight between 9,000 Da and 90,000 Da (Turner et al., 2012). In another study, two structural proteins of a novel Vibrio bacteriophage SIO-2, designated as the major capsid protein and the tape measure protein were estimated to be $29,000 \mathrm{Da}$ and 137,000 Da by SDS-PAGE, respectively (Baudoux et al., 2012). Besides, Han et al. (2013) have found that a Myoviridae phage SAH-1 possessed several structural proteins; mainly the major capsid and tail sheath proteins were predicted at $60,000 \mathrm{Da}$ and $78,000 \mathrm{Da}$ by SDSPAGE, respectively.

It is well known that bacteriophages are strictly hostspecific, which infects only one bacterial species or one serotype within a species (Ackermann et al., 1978; Bielke et al., 2007; Koskella and Meaden, 2013). However, not all bacteriophages are host-specific. Particularly, wide host range bacteriophages would be expected to be advantaged relative to phages with narrow host range, since a wide host range allows a phage to utilize one prey species when another is not available, or even utilize several simultaneously. For instance, phage SEA2 (Akhtar et al., 2014), phage Bc431v3 (El-Arabi et al., 2013) and phage JG004 (Garbe et al., 2011) were reported as broad host range bacteriophage against Salmonella enterica serovars, Bacillus species and Pseudomonas aeruginosa mutant strains, respectively. Turki et al. (2012) had isolated two bacteriophages, Salmonella Zanzibar phage sww275 and Salmonella Anatum phage sww65, which lytic on more than ten Salmonella strains, and were able to infect Escherichia coli and Citrobacter isolates. Interestingly, four Escherichia coli bacteriophages isolated from Lake Michigan showed lysis against Arthrobacter, Chryseobacterium, Microbacterium and Pseudomonas aeruginosa, exhibiting a width of host range capacity (Malki et al., 2015).

Upon infecting its host bacteria, most of the virulent phages act optimally at different ratio of multiplicity of infection (MOI). For example, the optimal MOI of a virulent bacteriophage KSL-1 specific for Pseudomonas fluorescens was determined to be 0.001 (Sun et al., 2012). Li and Zhang (2014) had isolated a lytic Staphylococcus aureus bacteriophage SPW from wastewater of cleaning dairy cattle udders with the optimal MOI of 0.01 . On the contrary, a lower MOI ratio of 0.0001 was reported for bacteriophage AB1 of Acinetobacter baumannii (Yang et al., 2010). Recently, higher ratio of 0.1 was considered as the optimal MOI for Escherichia phage CICC 80001 (Xu et al., 2016) and Salmonella Typhimurium phage $\Phi$ st 1 (Wong et al., 2014). Meanwhile, the proliferation rate of bacteriophages always depends on their latent period and burst size along with the number of infected cells. Abedon and Culler (2007) showed that an optimal latent period would improve phage fitness and an increase in burst size might affect the plaque sizes. It has also been demonstrated that latent period and burst size are influenced by the host, the medium compositions, the incubation temperature and the specific growth rate (Carey-Smith et al., 2006). Studies on the proliferation of bacteriophages have been reported in different latent periods and burst sizes (Table 2).

Most of the phages generally appear to be active over a broad $\mathrm{pH}$ range, from acidic to alkaline. Zhang et al. (2015) have reported a lytic phage of Lactobacillus casei isolated from Chinese sauerkraut was stable between $\mathrm{pH} 4.0$ and 11.0. A novel cold-active bacteriophage VNPH-1 specific for Aeromonas sobria was comparatively stable at $\mathrm{pH} 5.0$ to 10.0 and the optimum phage infectivity occurred at pH 9.0 (Ji et al., 2015). Similarly, Salmonella-infecting bacteriophages 
include phage PA13076 (Bao et al., 2015), phage SE2 (Tiwari et al., 2013), phage PSPu-95 and phage PSPu-4116 (Bao et al., 2011), were relatively stable within the $\mathrm{pH}$ range of 4.0 to 10.0. However, recent studies by $\mathrm{Hu}$ et al. (2016) on thirteen lytic distinct Pseudomonas bacteriophages reported that all phages were active over a very narrow $\mathrm{pH}$ range, from 6.0 to 7.0.

Table 2. Latent period and burst size of bacteriophages

\begin{tabular}{|c|c|c|c|}
\hline Phage & $\begin{array}{c}\text { Latent } \\
\text { period } \\
(\mathrm{min})\end{array}$ & $\begin{array}{c}\text { Burst } \\
\text { size } \\
(\mathrm{PFU} / \\
\text { cell) }\end{array}$ & Reference \\
\hline SE2 & 10 & 155 & Tiwari et al. (2013) \\
\hline CICC 80001 & 10 & 198 & Xu et al. (2016) \\
\hline$\varphi$ PA-HF17 & 10 & 200 & Han et al. (2014) \\
\hline $\mathrm{AB} 1$ & 18 & 409 & Yang et al. (2010) \\
\hline PSPu-4-116 & 20 & 86 & Bao et al. (2011) \\
\hline SAH-1 & 20 & 100 & Han et al. (2013) \\
\hline MJ1 & 21 & 300 & Jamal et al. (2015) \\
\hline JBP901 & 27 & 100 & Shin et al. (2011) \\
\hline JG004 & 31 & 13 & Garbe et al. (2011) \\
\hline Фst 1 & 40 & 22 & Wong et al. (2014) \\
\hline FGCSSa1 & 50 & 139 & $\begin{array}{l}\text { Carey-Smith et al. } \\
(2006)\end{array}$ \\
\hline Lcb & 75 & 16 & Zhang et al. (2015) \\
\hline Bc431v3 & 80 & 318 & El-Arabi et al. (2013) \\
\hline KSL-1 & 90 & 52 & Sun et al. (2012) \\
\hline$\Phi 22$ & 110 & 55 & $\begin{array}{l}\text { Pringsulaka et al. } \\
(2011)\end{array}$ \\
\hline
\end{tabular}

Reports showed that the viability of bacteriophages is greatly affected by temperature (Yang et al., 2010; Baudoux et al., 2012; Kęsik-Szeloch et al., 2013; Wong et al., 2014), which specifically influencing in their attachment, penetration, multiplication, and the length of the latent period (Jończyk et al., 2011). Most bacteriophages act optimally at temperatures between 30 $-50^{\circ} \mathrm{C}$ (Bao et al., 2015; Ji et al., 2015; Zhang et al., 2015). Bacteriophages were also found to be active over the temperature range of $4-50^{\circ} \mathrm{C}$ (Jun et al., 2013) and 4$60^{\circ} \mathrm{C}$ (Easwaran et al., 2015) for Shigella flexneri phage pSf-1 and Escherichia coli phage Sw1, respectively. Significant inactivates of phages were observed at $70^{\circ} \mathrm{C}$ for Siphoviridae (Lee et al., 2013), Myoviridae (Jamal et al., 2015) and Podoviridae (Augustine et al., 2013). On the contrary, Escherichia coli O157:H7 phage BECP2 (Lee and Park, 2015), Pseudomonas aeruginosa phage $\varphi$ PA-HF17 (Han et al., 2014), and Weissella cibaria phage $\Phi 22$ (Pringsulaka et al., 2011) showed heat resistance at $70^{\circ} \mathrm{C}$.

\section{Application of bacteriophages}

Nowadays, bacteriophages have contributed a lot to the field of molecular biology and biotechnology, and numerous applications have already been developed. The wide applications of phages in agriculture, clinical use, diagnosis of the disease, veterinary bio-control and also food safety have been studied extensively (Heringa et al., 2010; Larbanoix et al., 2011; Bardina et al., 2012; Jaiswal et al., 2013; Zinno et al., 2014; Liu et al., 2015; Lone et al., 2016).

\subsection{Therapeutic agents}

Bacteriophages have been extensively used to combat various bacterial infections after their discovery in the early $20^{\text {th }}$ century. For example, d'Herelle had employed bacteriophages as therapeutic agents in 1929 (Madhusudana Rao and Lalitha, 2015). Although the use of bacteriophages as therapeutic agents subsequently declined in the West, however, the emerging of various antibiotic-resistant bacteria have prompted the Western world to revive the interest of phage therapy in recent times (Jaiswal et al., 2013). In addition, phage therapy has been used in animals, plants, and humans with different degree of success (Haq et al., 2012). Several potential beneficial effects of phage therapy are: (i) narrow antibacterial spectrum allowing preservation of the existing microbiome, (ii) activity against both Grampositive and Gram-negative bacteria, (iii) less importance of side effects, (iv) extensive distribution upon systemic administration, (v) possible effect on the inflammatory response, (vi) improved efficacy as compared with antibiotics, and (vii) cost-effectiveness (Wittebole et al., 2014).

\subsection{Detection of bacterial pathogens}

The specificity of the interaction of a phage with its host cell immediately lends itself to methods for the identification of bacteria, in particular, the pathogens. One of the first uses of phage was in typing schemes, where a panel of phages with different lytic spectra is used to discriminate between different isolates of a bacterial species or genus, according to their ability to infect the isolate and form plaques. There are several methods can be used for pathogenic bacteria detection. For example, the use of bacteriophages which able to deliver reporter genes (e.g., $\operatorname{lu} x A B$ ) (Thouand et al., 2008) or using green fluorescent protein (Piuri et al., 2009) that would express after infection of bacteria. Besides, bacteriophages covalently attached with a fluorescent dye to their coats can be employed for the detection of specific adsorption (Goodridge et al., 1999). In certain cases, detection of other released components, which include adenosine triphosphate (ATP), adenylate kinase (AK) and $\beta$-D-galactosidase after the specific lysis 
Table 3. Bacteriophages used for bio-control in various foods

\begin{tabular}{llll}
\hline \multicolumn{1}{c}{ Target species } & \multicolumn{1}{c}{ Treated food } & \multicolumn{1}{c}{ Bacteriophage } & \multicolumn{1}{c}{ Reference } \\
\hline Bacillus cereus & Fermented food & JBP901 & Shin et al. (2011) \\
\hline Campylobacter jejuni & Raw and cooked beef meat & Cj6 & Bigwood et al. (2008) \\
\hline \multirow{2}{*}{ Escherichia coli O157:H7 } & Beef meat & FAHEc1 & Hudson et al. (2013) \\
& Turkey breast and raw beef meat & EcoM-AG10 & Anany et al. (2011) \\
\hline Listeria monocytogenes & Turkey breast and raw beef meat & LmoM-AG13 and LmoM-AG20 & Anany et al. (2011) \\
& RTE foods & A511 and P100 & Guenther et al. (2009) \\
\hline Salmonella enterica & Chicken breast, cabbage and milk & PA13076 and PC2184 & Bao et al. (2015) \\
& RTE foods & FO1-E2 & Guenther et al. (2012) \\
\hline Staphylococcus aureus & Fresh and hard-type cheese & phi-IPLA35 and phi-IPLA88 & Bueno et al. (2012) \\
\hline Vibrio parahaemolyticus & Oysters & VPp1 & Rong et al. (2014) \\
\hline
\end{tabular}

of bacteria can also be used (Guzmán Luna et al., 2009; Lee et al., 2011; Chen et al., 2015).

On the other hand, bacteriophage amplification assays attributed an attractive alternative method to detect pathogenic bacteria, which retained the inherent biological specificity of the phage for its target but utilized an assay end-point that was not dependent upon a genetically modified virion (Stewart et al., 1998; Schmelcher and Loessner, 2014). This technique has the advantage of detecting only viable cells. Therefore, it has most extensively been used for the detection of Campylobacter, Escherichia coli, Listeria, Mycobacterium tuberculosis, Pseudomonas, and Salmonella (Stewart et al., 1998; Pai et al., 2005; Oliveira et al., 2012).

\subsection{As bio-control agents in food industry}

Food-borne illnesses of microbial origin are serious food safety problems worldwide. With the current concern over the emerging of antibiotic-resistant foodborne pathogens resulted from the abuse and misuse of antibiotics, bacteriophage-based bio-control may serve as an alternative antimicrobial, which represents an economically viable field in the food industry (Henry and Debarbieux, 2012; Tan et al., 2014). Many studies reported success in decreasing the bacterial load (for Campylobacter, Listeria, Salmonella, and others) in a variety of foods (Table 3 ).

Several systems have already been approved by authorities with the "generally recognized as safe" (GRAS) status for use on food products such as ListShield $^{\mathrm{TM}}$ (Intralytix) or LISTEX ${ }^{\mathrm{TM}}$ (Micreos) for the control of Listeria monocytogenes (both FDA- and USDA-approved), EcoShield ${ }^{\mathrm{TM}}$ (FDA-cleared) targeting Escherichia coli O157:H7 and SALMONELEX ${ }^{\mathrm{TM}}$ against Salmonella (Henry and Debarbieux, 2012). Importantly, the efficacy of bacteriophages in food depends on the structure and chemical composition of the different food items, as well as sufficient diffusion ability of the phage particles, is necessary (Guenther et al., 2009). Furthermore, phage effectiveness is also influenced by $\mathrm{pH}$ and activity on a solid substrate or biofilm, the emergence of resistant bacteria mutants, and the relative numbers of phages and host required to allow replication (Hudson et al., 2005; Oliveira et al., 2015).

The use of immobilized phage as packaging material to maintain the safety of fresh produce is a novel concept that could allow the controlled release of bacteriophage particles into the food and reduce bacteriophage waste during food treatment using spraying (Lone et al., 2016). Currently, bacteriophage cocktails were introduced into prototypes of packaging materials using different techniques: i) immobilizing on positively charged modified cellulose membranes, ii) impregnating paper with bacteriophage suspension, and iii) encapsulating in alginate beads followed by application of beads onto the paper, in order to enhance the safety of fresh produce and RTE meat (Lone et al., 2016). Interventions using bacteriophages can be performed at different or even multiple points in the food processing facility or throughout the food chain to enhance the control process. It has been suggested that Salmonella bacteriophages can be added by dipping or spraying or as a liquid to different food matrices (Spricigo et al., 2013; Zinno et al., 2014; Bao et al., 2015; Sukumaran et al., 2015).

\section{Conflict of Interest}

The authors declare no conflict of interest.

\section{Acknowledgments}

We would like to thank Chin Yih Zhet, Dayang Fredalina Basri and Che Wan Jasimah Bt Wan Mohamed Radzi for their help with revising this paper.

\section{References}

Abedon, S.T. and Culler, R.R. (2007). Optimizing bacteriophage plaque fecundity. Journal of Theoretical Biology, 249(3), 582-592. https:// doi.org/10.1016/j.jtbi.2007.08.006

Ackermann, H.W. (2007). 5500 Phages examined in the electron microscope. Archives of Virology, 152(2), 
227-243. https://doi.org/10.1007/s00705-006-0849-1

Ackermann, H.W., Audurier, A., Berthiaume, L., Jones, L.A., Mayo, J.A. and Vidaver, A.K. (1978). Guidelines for bacteriophage characterization. Advances in Virus Research, 23, 1-24. https:// doi.org/10.1016/S0065-3527(08)60096-2

Ackermann, H.W. and Dubow, M.S. (1987). General properties of tailed phages. In Viruses of Prokaryotes, Volume 2, p. 28. Boca Raton, FL: CRC Press.

Akhtar, M., Viazis, S. and Diez-Gonzalez, F. (2014). Isolation, identification and characterization of lytic, wide host range bacteriophages from waste effluents against Salmonella enterica serovars. Food Control, 38, 67-74. https://doi.org/10.1016/ j.foodcont.2013.09.064

Anany, H., Chen, W., Pelton, R. and Griffiths, M.W. (2011). Biocontrol of Listeria monocytogenes and Escherichia coli $\mathrm{O} 157: \mathrm{H} 7$ in meat by using phages immobilized on modified cellulose membranes. Applied and Environmental Microbiology, 77(18), 6379-6387. https://doi.org/10.1128/AEM.05493-11

Anderson, B., Rashid, M.H., Carter, C., Pasternack, G., Rajanna, C., Revazishvili, T., Dean, T., Senecal, A. and Sulakvelidze, A. (2011). Enumeration of bacteriophage particles, comparative analysis of the traditional plaque assay and real-time QPCR- and nanosight-based assays. Bacteriophage, 1, 86-93. https://doi.org/10.4161/bact.1.2.15456

Augustine, J., Louis, L., Varghese, S.M., Bhat, S.G. and Kishore, A. (2013). Isolation and partial characterization of FSP-1, a Salmonella specific lytic phage from intestinal content of broiler chicken. Journal of Basic Microbiology, 53(2), 111-120. https://doi.org/10.1002/jobm.201100319

Bao, H., Zhang, H. and Wang, R. (2011). Isolation and characterization of bacteriophages of Salmonella enterica serovar Pullorum. Poultry Science, 90(10), 2370-2377. https://doi.org/10.3382/ps.2011-01496

Bao, H., Zhang, P., Zhang, H., Zhou, Y., Zhang, L. and Wang, R. (2015). Bio-control of Salmonella Enteritidis in foods using bacteriophages. Viruses, 7 (8), 4836-4853. https://doi.org/10.3390/v7082847

Bardina, C., Spricigo, D.A., Cortés, P. and Llagostera, M. (2012). Significance of the bacteriophage treatment schedule in reducing Salmonella colonization of poultry. Applied and Environmental Microbiology, 78(18), 6600-6607. https:// doi.org/10.1128/AEM.01257-12

Baudoux, A.C., Hendrix, R.W., Lander, G.C., Bailly, X., Podell, S., Paillard, C., Johnson, J.E., Potter, C.S., Carragher, B. and Azam, F. (2012). Genomic and functional analysis of Vibrio phage SIO-2 reveals novel insights into ecology and evolution of marine siphoviruses. Environmental Microbiology, 14(8), 2071-2086. https://doi.org/10.1111/j.14622920.2011.02685.x

Bielke, L., Higgins, S., Donoghue, A., Donoghue, D. and Hargis, B.M. (2007). Salmonella host range of bacteriophages that infect multiple genera. Poultry Science, 86(12), 2536-2540. https://doi.org/10.3382/ ps.2007-00250

Bigwood, T., Hudson, J.A., Billington, C., Carey-Smith, G.V. and Heinemann, J.A. (2008). Phage inactivation of foodborne pathogens on cooked and raw meat. Food Microbiology, 25(2), 400-406. https://doi.org/10.1016/j.fm.2007.11.003

Bourdin, G., Schmitt, B., Guy, L.M., Germond, J.E., Zuber, S., Michot, L., Reuteler, G. and Brussow, H. (2014). Amplification and purification of T4-Like Escherichia coli phages for phage therapy: from laboratory to pilot scale. Applied and Environmental Microbiology, 80(4), 1469-1476. https:// doi.org/10.1128/AEM.03357-13

Brüssow, H. and Kutter, E. (2005). Phage ecology. In Kutter, E. and Sulakvelidze, A. (Eds). Bacteriophages: Biology and applications, p. 129163. Boca Raton, FL: CRC Press.

Bueno, E., García, P., Martínez, B. and Rodríguez, A. (2012). Phage inactivation of Staphylococcus aureus in fresh and hard-type cheeses. International Journal of Food Microbiology, 158, 23-27. https:// doi.org/10.1016/j.ijfoodmicro.2012.06.012

Carey-Smith, G.V., Billington, C., Cornelius, A.J., Hudson, J.A. and Heinemann, J.A. (2006). Isolation and characterization of bacteriophages infecting Salmonella spp. FEMS Microbiology Letters, 258(2), 182-186. https://doi.org/10.1111/j.15746968.2006.00217.x

Carlson, K. (2005). Working with bacteriophages: common techniques and methodological approaches. In Kutter, E. and Sulakvelidze, A. (Eds). Bacteriophages: Biology and applications, p. 437494. Boca Raton, FL: CRC Press.

Chen, J., Alcaine, S.D., Jiang, Z., Rotello, V.M. and Nugen, S.R. (2015). Detection of Escherichia coli in drinking water using $\mathrm{T} 7$ bacteriophage-conjugated magnetic probe. Analytical Chemistry, 87(17), 89778984. https://doi.org/10.1021/acs.analchem.5b02175

Cormier, J. and Janes, M. (2014). A double layer plaque assay using spread plate technique for enumeration of bacteriophage MS2. Journal of Virological Methods, 196, 86-92. https://doi.org/10.1016/ j.jviromet.2013.10.034 
Easwaran, M., Paudel, S., De Zoysa, M. and Shin, H.J. (2015). Functional characterization of a novel lytic phage EcSw isolated from Sus scrofa domesticus and its potential for phage therapy. Molecular and Cellular Probes, 29(3), 151-157. https:// doi.org/10.1016/j.mcp.2015.03.004

El-Arabi, T.F., Griffiths, M.W., She, Y.M., Villegas, A., Lingohr, E.J. and Kropinski, A.M. (2013). Genome sequence and analysis of a broad-host range lytic bacteriophage that infects the Bacillus cereus group. Virology Journal, 10, 48. https:// doi.org/10.1186/1743-422X-10-48

Elbreki, M., Ross, R.P., Hill, C., O’Mahony, J., McAuliffe, O. and Coffey, A. (2014). Bacteriophages and their derivatives as biotherapeutic agents in disease prevention and treatment. Journal of Viruses, 2014, 20. https:// doi.org/10.1155/2014/382539

Garbe, J., Bunk, B., Rohde, M. and Schobert, M. (2011). Sequencing and Characterization of Pseudomonas aeruginosa phage JG004. BMC Microbiology, 11, 102. https://doi.org/10.1186/1471-2180-11-102

Goodridge, L. and Abedon, S.T. (2003). Bacteriophage biocontrol and bioprocessing: application of phage therapy to industry. Feature Article, 53, 254-262.

Goodridge, L., Chen, J. and Griffiths, M. (1999). Development and characterization of a fluorescentbacteriophage assay for detection of Escherichia coli O157:H7. Applied and Environmental Microbiology, 65(4), 1397-1404.

Guenther, S., Herzig, O., Fieseler, L., Klumpp, J. and Loessner, M.J. (2012). Biocontrol of Salmonella Typhimurium in RTE foods with the virulent bacteriophage FO1-E2. International Journal of Food Microbiology, 154, 66-72. https:// doi.org/10.1016/j.jifoodmicro.2011.12.023

Guenther, S., Huwyler, D., Richard, S. and Loessner, M.J. (2009). Virulent bacteriophage for efficient biocontrol of Listeria monocytogenes in ready-to-eat foods. Applied and Environmental Microbiology, 75 (1), 93-100. https://doi.org/10.1128/AEM.01711-08

Guzmán Luna, C., Costán-Longares, A., Lucena, F. and Jofre, J. (2009). Detection of somatic coliphages through a bioluminescence assay measuring phage mediated release of adenylate kinase and adenosine 5'-triphosphate. Journal of Virological Methods, 161, 107-113. https://doi.org/10.1016/ j.jviromet.2009.05.021

Han, F., Li, J., Lu, Y., Wen, J., Zhang, Z. and Sun, Y. (2014). Isolation and characterization of a virulent bacteriophage $\varphi$ PA-HF17 of Pseudomonas aeruginosa. International Journal Bioautomation,
$18,241-250$.

Han, J.E., Kim, J.H., Hwang, S.Y., Caoresca Jr, C.H., Shin, S.P., Jun, J.W., Chai, J.Y., Park, Y.H. and Park, S.C. (2013). Isolation and characterization of a Myoviridae bacteriophage against Staphylococcus aureus isolated from dairy cows with mastitis. Research in Veterinary Science, 95(2), 758-763. https://doi.org/10.1016/j.rvsc.2013.06.001

Hanlon, G.W. (2007). Bacteriophages: an appraisal of their role in the treatment of bacterial infections. International Journal of Antimicrobial Agents, 30(2), 118-128.

https://doi.org/10.1016/

j.ijantimicag.2007.04.006

Haq, I.U., Chaudhry, W.N., Akhtar, M.N., Andleeb, S. and Qadri, I. (2012). Bacteriophages and their implications on future biotechnology: a review. Virology Journal, 9, 9. https://doi.org/10.1186/1743422X-9-9

Henry, M. and Debarbieux, L. (2012). Tools from viruses: bacteriophage successes and beyond. Virology, 434, 151-161. https://doi.org/10.1016/ j.virol.2012.09.017

Heringa, S.D., Kim, J.K., Jiang, X., Doyle, M.P. and Erickson, M.C. (2010). Use of a mixture of bacteriophages for biological control of Salmonella enterica strains in compost. Applied and Environmental Microbiology, 76(15), 5327-5332. https://doi.org/10.1128/AEM.00075-10

Hu, Z., Meng, X.C. and Liu, F. (2016). Isolation and characterisation of lytic bacteriophages against Pseudomonas spp., a novel biological intervention for preventing spoilage of raw milk. International Dairy Journal, 55, 72-78. https://doi.org/10.1016/ j.idairyj.2015.11.011

Hudson, J.A., Billington, C., Carey-Smith, G. and Greening, G. (2005). Bacteriophages as biocontrol agents in food. Journal of Food Protection, 68(2), 426-437. 68.2 .426

Hudson, J.A., Billington, C., Cornelius, A.J., Wilson, T., On, S.L.W., Premaratne, A. and King, N.J. (2013). Use of a bacteriophage to inactivate Escherichia coli O157:H7 on beef. Food Microbiology, 36(1), 14-21. https://doi.org/10.1016/j.fm.2013.03.006

Jaiswal, A., Koley, H., Ghosh, A., Palit, A. and Sarkar, B. (2013). Efficacy of cocktail phage therapy in treating Vibrio cholerae infection in rabbit model. Microbes and Infection, 15(2), 152-156. https:// doi.org/10.1016/j.micinf.2012.11.002

Jamal, M., Hussain, T., Das, C.R. and Andleeb, S. (2015). Isolation and characterization of a Myoviridae MJ1 bacteriophage against multi-drug 
resistant Escherichia coli 3. Jundishapur Journal of Microbiology, 8(11), e25917. https:// doi.org/10.5812/jjm.25917

Ji, X., Yu, H., Zhang, Q., Lin, L. and Wei, Y. (2015). Isolation and characterization of a novel lytic coldactive bacteriophage VNPH-1 from the Napahai wetland in China. Annals of Microbiology, 65(3), 1789-1796. https://doi.org/10.1007/s13213-014-1018 $-5$

Jończyk, E., Kłak, M., Międzybrodzki, R. and Górski, A. (2011). The influence of external factors on bacteriophages-review. Folia Microbiologica, 56(3), 191-200. https://doi.org/10.1007/s12223-011-0039-8

Jun, J.W., Kim, J.H., Shin, S.P., Han, J.E., Chai, J.Y. and Park, S.C. (2013). Characterization and complete genome sequence of the Shigella bacteriophage pSf1. Research in Microbiology, 164(10), 979-986. https://doi.org/10.1016/j.resmic.2013.08.007

Kęsik-Szeloch, A., Drulis-Kawa, Z., Weber-Dąbrowska, B., Kassner, J., Majkowska-Skrobek, G., Augustyniak, D., Lusiak-Szelachowska, M., Zaczek, M., Górski, A. and Kropinski, A.M. (2013). Characterising the biology of novel lytic bacteriophages infecting multidrug resistant Klebsiella pneumoniae. Virology Journal, 10, 100. https://doi.org/10.1186/1743-422X-10-100

Kleiner, M., Hooper, L.V. and Duerkop, B.A. (2015). Evaluation of methods to purify virus-like particles for metagenomic sequencing of intestinal viromes. BMC Genomics, 16, 7. https://doi.org/10.1186/ s12864-014-1207-4

Koskella, B. and Meaden, S. (2013). Understanding bacteriophage specificity in natural microbial communities. Viruses, 5(3), 806-823. https:// doi.org/10.3390/v5030806

Kutter, E. and Sulakvelidze, A. (Eds.) (2005). Introduction. In Bacteriophages: Biology and applications, p. 1-4. Boca Raton, FL: CRC Press.

Larbanoix, L., Burtea, C., Ansciaux, E., Laurent, S., Mahieu, I., Elst, L.V. and Muller, R.N. (2011). Design and evaluation of a 6-mer amyloid-beta protein derived phage display library for molecular targeting of amyloid plaques in Alzheimer's disease: comparison with two cyclic heptapeptides derived from a randomized phage display library. Peptides, 32(6), 1232-1243. https://doi.org/10.1016/ j.peptides.2011.04.026

Lee, H.J., Ho, M.R., Tseng, C.S., Hsu, C.Y., Huang, M.S., Peng, H.L. and Chang, H.Y. (2011). Exponential ATP amplification through simultaneous regeneration from AMP and pyrophosphate for luminescence detection of bacteria. Analytical Biochemistry, 418(1), 19-23. https://doi.org/10.1016/j.ab.2011.07.013

Lee, Y.D., Kim, J.Y. and Park, J.H. (2013). Characteristics of coliphage ECP4 and potential use as a sanitizing agent for biocontrol of Escherichia coli O157:H7. Food Control, 34, 255-260. https:// doi.org/10.1016/j.foodcont.2013.04.043

Lee, Y.D. and Park, J.H. (2015). Characterization and application of phages isolated from sewage for reduction of Escherichia coli O157: H7 in biofilm. LWT - Food Science and Technology, 60, 571-577. https://doi.org/10.1016/j.lwt.2014.09.017

Lenski, R.E. (1988). Dynamics of interactions between bacteria and virulent bacteriophage. Advances in Microbial Ecology, 10, 1-44. https://doi.org/10.1016/ j.lwt.2014.09.017

Li, L. and Zhang, Z. (2014). Isolation and characterization of a virulent bacteriophage $S P W$ specific for Staphylococcus aureus isolated from bovine mastitis of lactating dairy cattle. Molecular Biology Reports, 41(9), 5829-5838. https:// doi.org/10.1007/s11033-014-3457-2

Lin, N.T., Chiou, P.Y., Chang, K.C., Chen, L.K. and Lai, M.J. (2010). Isolation and characterization of $\Phi A B 2$ : a novel bacteriophage of Acinetobacter baumannii. Research in Microbiology, 161, 308-314. https:// doi.org/10.1016/j.resmic.2010.03.007

Liu, H., Niu, Y.D., Meng, R., Wang, J., Li, J., Johnson, R.P., McAllister, T.A. and Stanford, K. (2015). Control of Escherichia coli $\mathrm{O} 157$ on beef at 37, 22 and $4^{\circ} \mathrm{C}$ by T5-, T1-, T4-and O1-like bacteriophages. Food Microbiology, 51, 69-73. https:// doi.org/10.1016/j.fm.2015.05.001

Lone, A., Anany, H., Hakeem, M., Aguis, L., Avdjian, A.C., Bouget, M., Atashi, A., Brovko, L., Rochefort, D. and Griffiths, M.W. (2016). Development of prototypes of bioactive packaging materials based on immobilized bacteriophages for control of growth of bacterial pathogens in foods. International Journal of Food Microbiology, 217, 49-58. https:// doi.org/10.1016/j.ijfoodmicro.2015.10.011

Lopes, A., Tavares, P., Petit, M.A., Guérois, R. and Zinn -Justin, S. (2014). Automated classification of tailed bacteriophages according to their neck organization. BMC Genomics, 15, 1027. https:// doi.org/10.1186/1471-2164-15-1027

Madhusudana Rao, B. and Lalitha, K.V. (2015). Bacteriophages for aquaculture: are they beneficial or inimical. Aquaculture, 437, 146-154. https:// doi.org/10.1016/j.aquaculture.2014.11.039

Malki, K., Kula, A., Bruder, K., Sible, E., Hatzopoulos, T., Steidel, S., Watkins, S.C. and Putonti, C. (2015) 
Bacteriophages isolated from Lake Michigan demonstrate broad host-range across several bacterial phyla. Virology Journal, 12, 164. https:// doi.org/10.1186/s12985-015-0395-0

Oliveira, I.C., Almeida, R.C.C., Hofer, E. and Almeida, P.F. (2012). Bacteriophage amplification assay for detection of Listeria spp. using virucidal laser treatment. Brazilian Journal of Microbiology, 43(3), 1128-1136. 83822012000300040

Oliveira, M., Abadias, M., Colás-Medà, P., Usall, J. and Viñas, I. (2015). Biopreservative methods to control the growth of foodborne pathogens on fresh-cut lettuce. International Journal of Food Microbiology, 214, 4-11. https://doi.org/10.1016/ j.ijfoodmicro.2015.07.015

Pai, M., Kalantri, S., Pascopella, L., Riley, L.W. and Reingold, A.L. (2005). Bacteriophage-based assays for the rapid detection of rifampicin resistance in Mycobacterium tuberculosis: a meta-analysis. Journal of Infection, 51(3), 175-187. https:// doi.org/10.1016/j.jinf.2005.05.017

Peng, Y., Jin, Y., Lin, H., Wang, J. and Khan, M.N. (2014). Application of the VPp1 bacteriophage combined with a coupled enzyme system in the rapid detection of Vibrio parahaemolyticus. Journal of Microbiological Methods, 98, 99-104. https:// doi.org/10.1016/j.mimet.2014.01.005

Piuri, M., Jacobs Jr, W.R. and Hatfull, G.F. (2009). Fluoromycobacteriophages for rapid, specific, and sensitive antibiotic susceptibility testing of Mycobacterium tuberculosis. PLoS One, 4, e4870. https://doi.org/10.1371/journal.pone.0004870

Pope, W.H., Weigele, P.R., Chang, J., Pedulla, M.L., Ford, M.E., Houtz, J.M., Jiang, W., Chiu, W., Hatfull, G.F., Hendrix, R.W. and King, J. (2007). Genome sequence, structural proteins, and capsid organization of the cyanophage Syn5: a "horned" bacteriophage of marine Synechococcus. Journal of Molecular Biology, 368(4), 966-981. https:// doi.org/10.1016/j.jmb.2007.02.046

Premarathne, J.M.K.J.K., Thung, T.Y., New, C.Y., Huat, J.T.Y., Basri, D.F., Rukayadi, Y., Nakaguchi, Y., Nishibuchi, M. and Son, R. (2017). Distribution of bacteriophages in food and environment samples. International Food Research Journal, 24(2), 888896.

Pringsulaka, O., Patarasinpaiboon, N., Suwannasai, N., Atthakor, W. and Rangsiruji, A. (2011). Isolation and characterisation of a novel Podoviridae-phage infecting Weissella cibaria N 22 from Nham, a Thai fermented pork sausage. Food Microbiology, 28(3), 518-525. https://doi.org/10.1016/j.fm.2010.10.011
Ranquet, C., Toussaint, A., de Jong, H., MaenhautMichel, G. and Geiselmann, J. (2005). Control of Bacteriophage Mu Lysogenic Repression. Journal of Molecular Biology, 353(1), 186-195. https:// doi.org/10.1016/j.jmb.2005.08.015

Ripp, S. and Miller, R.V. (1997). The role of pseudolysogeny in bacteriophage-host interactions in a natural freshwater environment. Microbiology, 143, 2065-2070. https://doi.org/10.1099/00221287143-6-2065

Ripp, S. and Miller, R.V. (1998). Dynamics of the pseudolysogenic response in slowly growing cells of Pseudomonas aeruginosa. Microbiology, 144, 22252232. https://doi.org/10.1099/00221287-144-8-2225

Rong, R., Lin, H., Wang, J., Khan, M.N. and Li, M. (2014). Reductions of Vibrio parahaemolyticus in oysters after bacteriophage application during depuration. Aquaculture, 418-419, 171-176. https:// doi.org/10.1016/j.aquaculture.2013.09.028

Santos, S.B., Kropinski, A.M., Ceyssens, P.J., Ackermann, H.W., Villegas, A., Lavigne, R., Krylov, V.N., Carvalho, C.M., Ferreira, E.C. and Azeredo, J. (2011). Genomic and proteomic characterization of the broad-host-range Salmonella phage PVP-SE1: creation of a new phage genus. Journal of Virology, 85(21), 11265-11273. https:// doi.org/10.1128/JVI.01769-10

Schmelcher, M. and Loessner, M.J. (2014). Application of bacteriophages for detection of foodborne pathogens. Bacteriophage, 4, e28137. https:// doi.org/10.4161/bact.28137

Shin, H., Bandara, N., Shin, E., Ryu, S. and Kim, K. (2011). Prevalence of Bacillus cereus bacteriophages in fermented foods and characterization of phage JBP901. Research in Microbiology, 162, 791-797. https://doi.org/10.1016/j.resmic.2011.07.001

Spricigo, D.A., Bardina, C., Cortés, P. and Llagostera, M. (2013). Use of a bacteriophage cocktail to control Salmonella in food and the food industry. International Journal of Food Microbiology, 165, 169-174.

https://doi.org/10.1016/ j.ijfoodmicro.2013.05.009

Stewart, G.S.A.B., Jassim, S.A.A., Denyer, S.P., Newby, P., Linley, K. and Dhir, V.K. (1998). The specific and sensitive detection of bacterial pathogens within $4 \mathrm{~h}$ using bacteriophage amplification. Journal of Applied Microbiology, 84(5), 777-783. https:// doi.org/10.1046/j.1365-2672.1998.00408.x

Sukumaran, A.T., Nannapaneni, R., Kiess, A. and Sharma, C.S. (2015). Reduction of Salmonella on chicken meat and chicken skin by combined or sequential application of lytic bacteriophage with 
chemical antimicrobials. International Journal of Food Microbiology, 207, 8-15. https:// doi.org/10.1016/j.ijfoodmicro.2015.04.025

Sulakvelidze, A., Alavidze, Z. and Morris Jr., J.G. (2001). Bacteriophage therapy. Antimicrobial Agents Chemotherapy, 45(3), 649-659. https:// doi.org/10.1128/AAC.45.3.649-659.2001

Sulakvelidze, A. and Barrow, P. (2005). Phage therapy in animals and agribusiness. In Kutter, E. and Sulakvelidze, A. (Eds). Bacteriophages: Biology and applications, p. 335-380. Boca Raton, FL: CRC Press.

Sun, W.J., Liu, C.F., Yu, L., Cui, F.J., Zhou, Q., Yu, S.L. and Sun, L. (2012). A novel bacteriophage KSL-1 of 2-Keto-gluconic acid producer Pseudomonas fluorescens K1005: isolation, characterization and its remedial action. BMC Microbiology, 12, 127. https:// doi.org/10.1186/1471-2180-12-127

Tan, L.T.H., Chan, K.G. and Lee, L.H. (2014). Application of bacteriophage in biocontrol of major foodborne bacterial pathogens. Journal of Molecular Biology and Molecular Imaging, 1, 9.

Thouand, G., Vachon, P., Liu, S., Dayre, M. and Griffiths, M.W. (2008). Optimization and validation of a simple method using P22::luxAB bacteriophage for rapid detection of Salmonella enterica serotypes A, B, and D in poultry samples. Journal of Food Protection, 71(2), 380-385. https:// doi.org/10.4315/0362-028X-71.2.380

Thung, T.Y., Siti Norshafawatie, B.M.F., Premarathne, J.M.K.J.K., Chang, W.S., Loo, Y.Y., Kuan, C.H., New, C.Y., Ubong, A., Ramzi, O.S.B., Mahyudin, N.A., Dayang, F.B., Che Wan Jasimah, W.M.R. and Son, R. (2017). Isolation of food-borne pathogen bacteriophages from retail food and environmental sewage. International Food Research Journal, 24(1), 450-454.

Thurber, R.V., Haynes, M., Breitbart, M., Wegley, L. and Rohwer, F. (2009). Laboratory procedures to generate viral metagenomes. Nature Protocols, 4(4), 470-483. https://doi.org/10.1038/nprot.2009.10

Tiwari, B.R., Kim, S. and Kim, J. (2013). A Virulent Salmonella enterica serovar Enteritidis phage SE2 with a strong bacteriolytic activity of planktonic and biofilmed cells. Journal of Bacteriology and Virology, 43, 186-194. https://doi.org/10.4167/ jbv.2013.43.3.186

Turki, Y., Ouzari, H., Mehri, I., Ammar, A.B. and Hassen, A. (2012). Evaluation of a cocktail of three bacteriophages for the biocontrol of Salmonella of wastewater. Food Research International, 45, 10991105. https://doi.org/10.1016/j.foodres.2011.05.041
Turner, D., Hezwani, M., Nelson, S., Salisbury, V. and Reynolds, D. (2012). Characterization of the Salmonella bacteriophage vB_SenS-Ent1. Journal of General Virology, 93, 2046-2056. https:// doi.org/10.1099/vir.0.043331-0

Twort, F.W. (1915). An investigation on the nature of ultra-microscopic viruses. The Lancet, 2, 1241-1243. https://doi.org/10.1016/S0140-6736(01)20383-3

Weinbauer, M.G. (2004). Ecology of prokaryotic viruses. FEMS Microbiology Reviews, 28(2), 127181. https://doi.org/10.1016/j.femsre.2003.08.001

Wittebole, X., De Roock, S. and Opal, S.M. (2014). A historical overview of bacteriophage therapy as an alternative to antibiotics for the treatment of bacterial pathogens. Virulence, 5(1), 226-235. https:// doi.org/10.4161/viru.25991

Wong, C.L., Sieo, C.C., Tan, W.S., Abdullah, N., HairBejo, M., Abu, J. and Ho, Y.W. (2014). Evaluation of a lytic bacteriophage, $\Phi s t 1$, for biocontrol of Salmonella enterica serovar Typhimurium in chickens. International Journal of Food Microbiology, 172, 92-101. https://doi.org/10.1016/ j.ijfoodmicro.2013.11.034

Xu, Y., Ma, Y., Yao, S., Jiang, Z., Pei, J. and Cheng, C. (2016). Characterization, genome sequence, and analysis of Escherichia phage CICC 80001, a bacteriophage infecting an efficient L-Aspartic acid producing Escherichia coli. Food and Environmental Virology, 8(1), 18-26. https:// doi.org/10.1007/s12560-015-9218-0

Yang, H., Liang, L., Lin, S. and Jia, S. (2010). Isolation and characterization of a virulent bacteriophage AB1 of Acinetobacter baumannii. BMC Microbiology, 10, 131. https://doi.org/10.1186/1471-2180-10-131

Zhang, X., Lan, Y., Jiao, W., Li, Y., Tang, L., Jiang, Y., Cui, W. and Qiao, X. (2015). Isolation and characterization of a novel virulent phage of Lactobacillus casei ATCC 393. Food and Environmental Virology, 7(4), 333-341. https:// doi.org/10.1007/s12560-015-9206-4

Zinno, P., Devirgiliis, C., Ercolini, D., Ongeng, D. and Mauriello, G. (2014). Bacteriophage P22 to challenge Salmonella in foods. International Journal of Food Microbiology, 191, 69-74. https:// doi.org/10.1016/j.ijfoodmicro.2014.08.037 